\title{
Change of macrobenthic communities in the 1930s, 1970s and 2015 in the mesotrophic Lake Nojiri, Central Japan
}

\author{
Kimio HIRABAYASHI, ${ }^{*}$ Makoto ICHIKAWA, ${ }^{2}$ Shunsuke OKADA, ${ }^{2}$ Masaru YAMAMOTO ${ }^{3}$ \\ ${ }^{1}$ Division of Applied Biology, Institute of Textile Science and Technology, Academic Assembly, Shinshu University, 3-15-1, Tokida, \\ Ueda City, Nagano Prefecture, 386-8567; ${ }^{2}$ Department of Applied Biology, Faculty of Textile Science and Technology, Shinshu \\ University, 3-15-1, Tokida, Ueda City, Nagano Prefecture, 386-8567; ${ }^{3} 1-6-12$, Yoshimisato-machi, Shimonoseki City, Yamaguchi \\ Prefecture, 759-6525, Japan \\ *Corresponding author: kimio@shinshu-u.ac.jp
}

\begin{abstract}
We documented the current status of the macrobenthic community of Lake Nojiri (surface area: $4.56 \mathrm{~km}^{2}$; maximum depth: 38.5 $\mathrm{m}$; altitude: $654 \mathrm{~m}$ above sea level; mesotrophic lake), and examined changes over time in the densities of chironomids and oligochaetes, by comparison with previous quantitative data of the lake reported in 1931 and 1973 . We discussed the succession of benthic macroinvertebrates in relation to changes in the lake bottom environment, as evidence of lake eutrophication. On March 10, 2015, a bathymetrical sampling survey was carried out using a standard Ekman grab at each of the 5 stations (min. $c a .6 \mathrm{~m}-\mathrm{max} . c a .27 \mathrm{~m}$ ) in Lake Nojiri. The average densities of the benthic communities for all the stations were $c a .5000 \mathrm{~m}^{-2}$, comprised principally of oligochaetes ca. $2800 \mathrm{~m}^{-2}(57 \%)$ and chironomids $c a .2100 \mathrm{~m}^{-2}(43 \%)$, whereas their benthic biomass averaged $c a .9 .7 \mathrm{~g} \mathrm{~m}{ }^{-2}$, chironomids $c a .7 .6 \mathrm{~g} \mathrm{~m}^{-2}(77 \%)$ and oligochaetes $c a .2 .3 \mathrm{~g} \mathrm{~m}^{-2}(23 \%)$. In the shallower stations, the dominant species was Heterotrissocladius sp., but Chironomus nipponensis Tokunaga was the dominant species in the deeper stations. The densities of $C$. nipponensis was ca. 14 times higher than those reported by Miyadi in 1931 and 4 times higher than reported by Kitagawa in 1973a. In recent years the density of the oligochaete Tubifex tubifex (Miller), has tended to increase and the anoxic- and anaerobic-layer have thickened, especially in deeper regions where they are widely distributed. Moreover, we found differences in the C. nipponensis larval growth rate with water depth, i.e., small IV-instar larvae that dominated at the deepest Station 5. At this station, we suggest that low dissolved oxygen concentration and low water temperature during summer-fall suppresses growth of C. nipponensis. Large environmental changes must have affected chironomid and oligochaete densities and growth rate of $C$. nipponensis, especially in the deeper regions with low dissolved oxygen concentrations, low water temperature and high organic matter (ignition loss; $15.0 \%$ in St. 4 and $13.9 \%$ in St. 5) in the sediments. This is a strong evidence that the eutrophication of this lake is continuing.
\end{abstract}

Key words: Bathymetrical distribution; biomass; chironomids; Chironomus nipponensis Tokunaga; density; eutrophication; mountain lake; Tubifex tubifex (Miller).

Received: February 2018. Accepted: June 2018.

This paper was presented at the $20^{\text {th }}$ International Symposium on Chironomidae, Trento, Italy, 2-8 July 2017. Session: Autecology and Physiology.

\section{INTRODUCTION}

It has long been well known that indices based on species composition, density, biomass and the distribution of benthic fauna in lakes reveal the status and change of the lakes and their bottom environment (reviewed by Lindegaard, 1995). However, few studies on benthic macroinvertebrates, e.g. aquatic Oligochaeta and chironomid larvae, have been undertaken in Japan because of the difficulty of species identification (Yasuno et al., 1983). The biota of Lake Nojiri has been studied by many workers since Tanaka (1916). However, studies of benthic macroinvertebrates have been very few. Previous research on Lake Nojiri includes a descriptive study of benthic animals (Miyadi, 1931) and a description of the horizontal distribution of total Oligochaeta and chironomid larvae (Kitagawa, 1973a). Recently, Inoue et al. (2010) described the benthic macroinvertebrates in the profundal area of this lake. In 1978, five thousand grass carp, Ctenopharyngodon idellus, were introduced in order to manage the aquatic plants, which sometimes interfere with fishery and boat navigation. Three years after its introduction, most aquatic plants including genus Nitellopsis obtusa (stonewort) were heavily damaged or extinct due to overgrazing by grass carp (Higuchi, 2002). Moreover, large mouse bass, Micropterus salmoides, were introduced into the lake in the 2000s, and sports' fishing is also popular (Kitano et al., 2010). At the same time, reduced water transparency due to pollution from these activities has been a growing issue (Nagano Prefecture, 2015). Thus, from the end of the 1980 s to the end of the 2000s, the biota and the environmental conditions of the 
lake changed drastically (Tanaka, 1992, Nagano Prefecture, 2015), and this must have had some effect on the Oligochaeta and chironomid fauna.

The distribution of benthic macroinvertebrates was investigated to document the current status of the macrobenthic community of Lake Nojiri, especially oligochaetes and chironomid larvae, and to examine the difference with the quantitative data reported by Miyadi (1931) and Kitagawa (1973a). The succession of benthic macroinvertebrates in relation to changes in the lake bottom environment is currently under discussion.

\section{METHODS}

Lake Nojiri (36 $46^{\prime} 30^{\prime \prime} \mathrm{N}, 138^{\circ} 13^{\prime} 20^{\prime \prime} \mathrm{E}$ at the center of the lake) has a surface area of $3.90 \mathrm{~km}^{2}$, maximum and mean depths of 37.5 and $20.8 \mathrm{~m}$, respectively, and lies at an altitude of $654 \mathrm{~m}$ above sea level at the foot of Mt.
Kurohime. Aizaki et al. (1981) ranked this lake as mesotrophic, using the modified Carlson's Trophic State Index (TSI; Carlson 1977, 1980) based on transparency, chlorophyll- $a$ and total phosphorus. In some parts of the lake the water has been used as a drinking water source.

Larvae of some chironomid species, e.g., Propsilocerus akamusi (Tokunaga), burrow deep into the lake sediments to aestivate during the summer (Yamagishi and Fukuhara, 1972; Iwakuma and Yasuno, 1981). Thus, sampling benthic macroinvertebrates is most efficient from late-autumn to early-spring when almost all benthos stay close to the surface of the sediment. A multipoint sampling survey was carried out on 10 March 2015, using a standard Ekman grab $(15 \times 15 \mathrm{~cm})$. Three samples were taken at each of 5 sampling stations (St. 1: $6.2 \mathrm{~m}$; St. 2: 10.5 m; St. 3: 14.9 m; St. 4: 20.2 m; St. 5: 27.1 m) in Lake Nojiri (Fig. 1). The sampling points were determined with a Global Positioning System (GPS). After sieving the

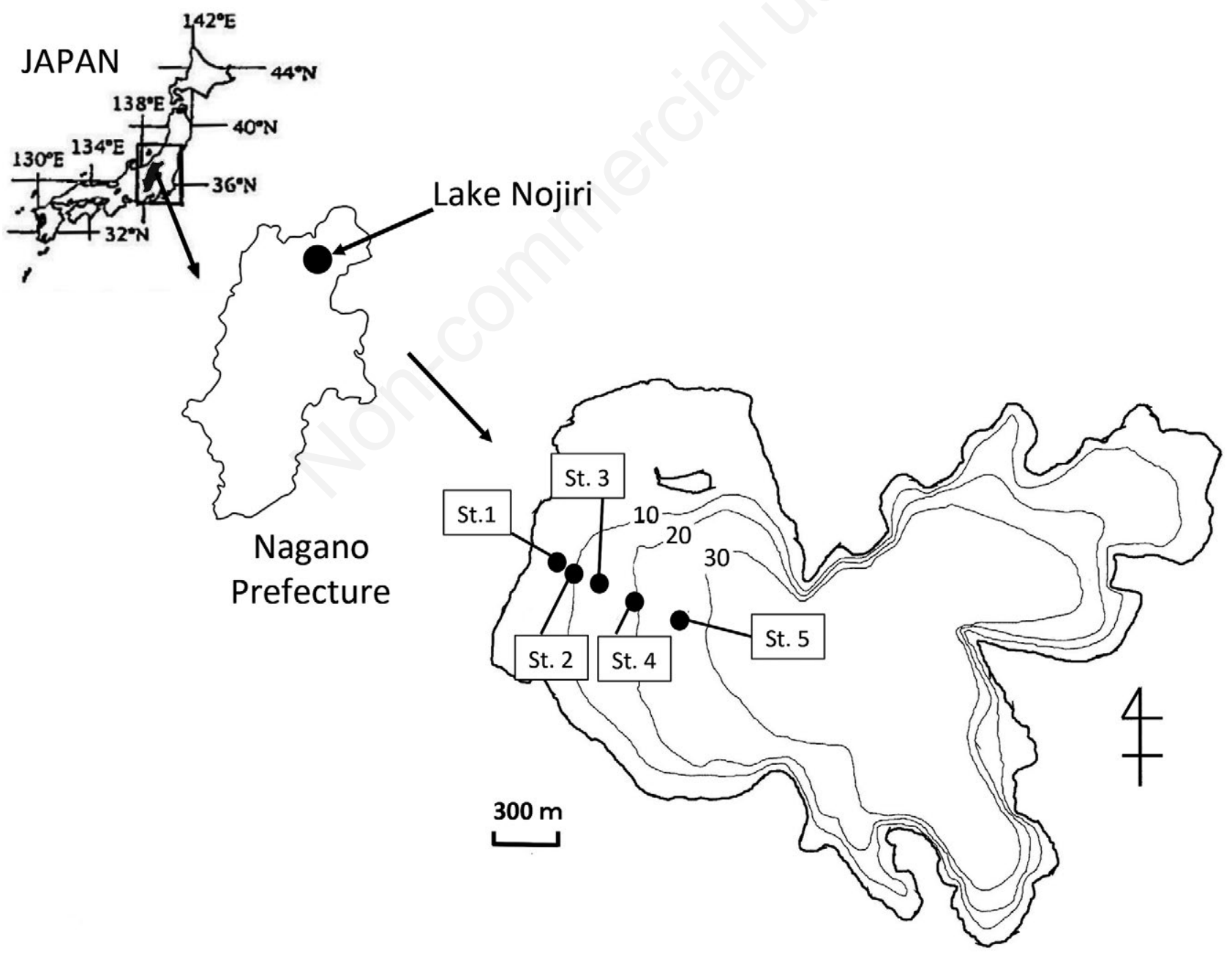

Fig. 1. Map of the sampling stations in Lake Nojiri. 
sediment through a Surber net (GG66; $0.25 \mathrm{~mm}$ mesh size) chironomid larvae and oligochaetes were counted in the laboratory. Their wet weight was measured with an electronic balance (AND, HM-202).

To identify the chironomids some larvae were soaked in a $10 \% \mathrm{KOH}$ solution, mounted on slides with gum chloral solution, and examined under a microscope. The chironomids were identified to genus using the keys of Cranston (1982), Wiederholm (1983) and Andersen et al. (2013). Reference was made to the list of adult chironomids in 2010 in Lake Nojiri reported by Inoue et al. (2010).

Sediment samples for organic matter analysis were collected with a core sampler $(3 \mathrm{~cm}$ inner diameter) at all stations. Mud from the upper $3 \mathrm{~cm}$ layer of each core was oven-dried at $110^{\circ} \mathrm{C}$ for 2 days and ignited in a muffle furnace at $550^{\circ} \mathrm{C}$ for three hours to determine the ignition loss (IL). At the same station, the core sampler was also used to measure dissolved oxygen concentrations (DO) in the water at the mud-water interface. The water near the mud surface in the core sampler (which remained above the sediment in the core sampler when it was pulled from the water) was siphoned carefully into a glass bottle. Dissolved oxygen concentration was measured using the Winkler method with azide modification. The bottom water temperature (WT) and mud temperature (MT) in the bottom sediments collected in the core sampler were also measured using a thermistor thermometer $(c a .3 \mathrm{~cm}$ from the sediment surface).

\section{RESULTS}

Dissolved oxygen and temperature at the mud-water interface varied little among stations in March 2015, because this was during the period of spring overturn. The ignition loss values of the sediment ranged from $9.6 \%$ to $15.0 \%$, with a mean value of $12.2 \pm 2.2 \%$. Most of the lake basin consisted of a soft bottom with an organic matter content higher than $11 \%$. Sediments at St. 4 contained the highest levels of organic matter (15.0\%).

The average density $( \pm \mathrm{SD})$ of the benthos for all the stations was $4961 \pm 2303 \mathrm{~m}^{-2}$ (Tab. 1), and was comprised principally of oligochaetes, $2809 \pm 2138 \mathrm{~m}^{-2}(56.6 \%)$ and chironomids, $2125 \pm 2320 \mathrm{~m}^{-2}$ (42.8\%). Average benthic biomass $9.66 \pm 4.71 \mathrm{~g} \mathrm{~m}^{-2}$ was dominated by chironomids at $7.64 \pm 4.64 \mathrm{~g} \mathrm{~m}^{-2}(77.2 \%)$ and oligochaetes at $2.26 \pm 1.56$ $\mathrm{g} \mathrm{m}^{-2}(22.8 \%)$. There were two species of Orthocladiinae, nine species of Chironominae, one Diamesinae and one Tanypodinae. The most abundant species was Heterotrissocladius sp. (36.1\%), followed by Chironomus nipponensis Tokunaga (24.4\%). C. nipponensis represented the highest biomass $(74.7 \%)$ followed by Heterotrissocladius sp. (14.7\%).

The densities of Tubifex tubifex (Miller) and total chironomid larvae were widely distributed with depth (Fig. 2). Although the density of total chironomid larvae and Heterotrissocladius sp. decreased with increasing water depth, their highest densities were in the shallowest

Tab. 1. Species composition, densities and biomass in Lake Nojiri on March 10, 2015.

\begin{tabular}{|c|c|c|c|c|}
\hline & Densities (ind $\mathrm{m}^{-2}$ ) & $\%$ & Biomass $\left(\mathrm{g} \mathrm{m}^{-2}\right)$ & $\%$ \\
\hline Chironomidae & $2125.3 \pm 2320.0$ & 42.8 & $7.64 \pm 4.64$ & 77.2 \\
\hline Tanypodinae & $222.0 \pm 171.1$ & 10.4 & $0.29 \pm 0.19$ & 3.8 \\
\hline \multicolumn{5}{|l|}{ Orthocladiinae } \\
\hline Heterotrissocladius sp. & $766.6 \pm 1615.2$ & 36.1 & $1.12 \pm 2.38$ & 14.7 \\
\hline Propsilocerus akamusi & $11.8 \pm 20.3$ & 0.6 & $0.16 \pm 0.33$ & 2.0 \\
\hline \multicolumn{5}{|l|}{ Chironominae } \\
\hline Chironomus nipponennsis & $518.0 \pm 463.1$ & 24.4 & $5.71 \pm 5.45$ & 74.7 \\
\hline Micropsectra sp. & $254.6 \pm 306.5$ & 12.0 & $0.18 \pm 0.26$ & 2.4 \\
\hline Tanytarsus sp. & $142.1 \pm 281.4$ & 6.7 & & \\
\hline Polypedilum sp. & $65.1 \pm 138.2$ & 3.1 & - & - \\
\hline Biwatendipes tsukubaensis & $35.5 \pm 79.1$ & 1.7 & - & - \\
\hline Cladopelma sp. & $17.8 \pm 49.8$ & 0.8 & - & - \\
\hline Stictochironomus multannulatus & $11.8 \pm 20.3$ & 0.6 & - & - \\
\hline Microchironomus sp. & $8.9 \pm 34.4$ & 0.4 & - & - \\
\hline Nilodosis sp. & $8.9 \pm 34.4$ & 0.4 & $0.01 \pm 0.02$ & 0.1 \\
\hline \multicolumn{5}{|l|}{ Diamesinae } \\
\hline Protanypus sp. & $5.9 \pm 22.9$ & 0.3 & $0.02 \pm 0.09$ & 0.3 \\
\hline Pupae of chironomidae & $29.6 \pm 62.0$ & 1.4 & $0.34 \pm 0.60$ & 2.0 \\
\hline Unknown & $26.6 \pm 52.5$ & 1.3 & - & - \\
\hline Oligochaetae (Tubifex tubifex) & $2809.0 \pm 2138.4$ & 56.6 & $2.26 \pm 1.56$ & 22.8 \\
\hline Others & $26.6 \pm 32.7$ & 0.5 & - & - \\
\hline Total & $4961.0 \pm 2302.7$ & & $9.66 \pm 4.71$ & \\
\hline
\end{tabular}


station. T. tubifex and C. nipponensis abundance increased with water depth; their highest densities were in the deeper regions (St. 4 and 5; more than $20 \mathrm{~m}$ ) and their lowest in the shallower regions (St. 1 and 2; less than $10 \mathrm{~m}$ ).

The frequency distribution of wet body weight of IVinstar larvae and of $C$. nipponensis at each station in Lake Nojiri, as of March 2015 showed striking differences with depth (Fig. 3). C. nipponensis larval growth rate varied with water depths. In deeper regions there are many relatively small IV-instar larvae (peak of frequency was 4-6 $\mathrm{mg}$ per larva), whereas in shallower regions there are many large IV-instar larvae (peak frequency was at 10-12 mg per larva).

\section{DISCUSSION}

Many researchers have used zoobenthos as indicators of the trophic state and organic pollution of lakes (reviewed by Sæther, 1979; Lindegaard, 1995). Brinkhurst (1974) reported density and biomass of benthos increasing with lake eutrophication. We compared our results with previous quantitative data on chironomids and oligochaetes reported by Miyadi (1931) and Kitagawa (1973a) to clarify trends in the benthic community composition. Miyadi (1931) and Kitagawa (1973a) collected the benthic fauna using a standard Ekman grab $(15 \times 15 \mathrm{~cm})$ and sieving the sediment through a wire netting with meshes of $0.5 \mathrm{~mm}$. Miyadi (1931) collected samples at 30 stations in April 28, 1928 and 10 stations in November 29, 1928. Kitagawa (1973a) collected samples at 12 stations in April 6, 1972 and 18 stations in August 22, 1972. Thus, our sampling stations were selected at similar depths (Tab. 2). Different species composition and relative abundance of single taxon were detected in our study respect to the two previous ones. For example, in 2015 Heterotrissocladius sp. were found in the bottom and dominated the shallower regions of the lake where it was absent in 1931 and 1973a. Furthermore, the density of the total Chironomidae and T. tubifex were 4.3 and 12.7 times higher than in 1931 and 1973a, respectively. In particular, the density of T. tubifex has

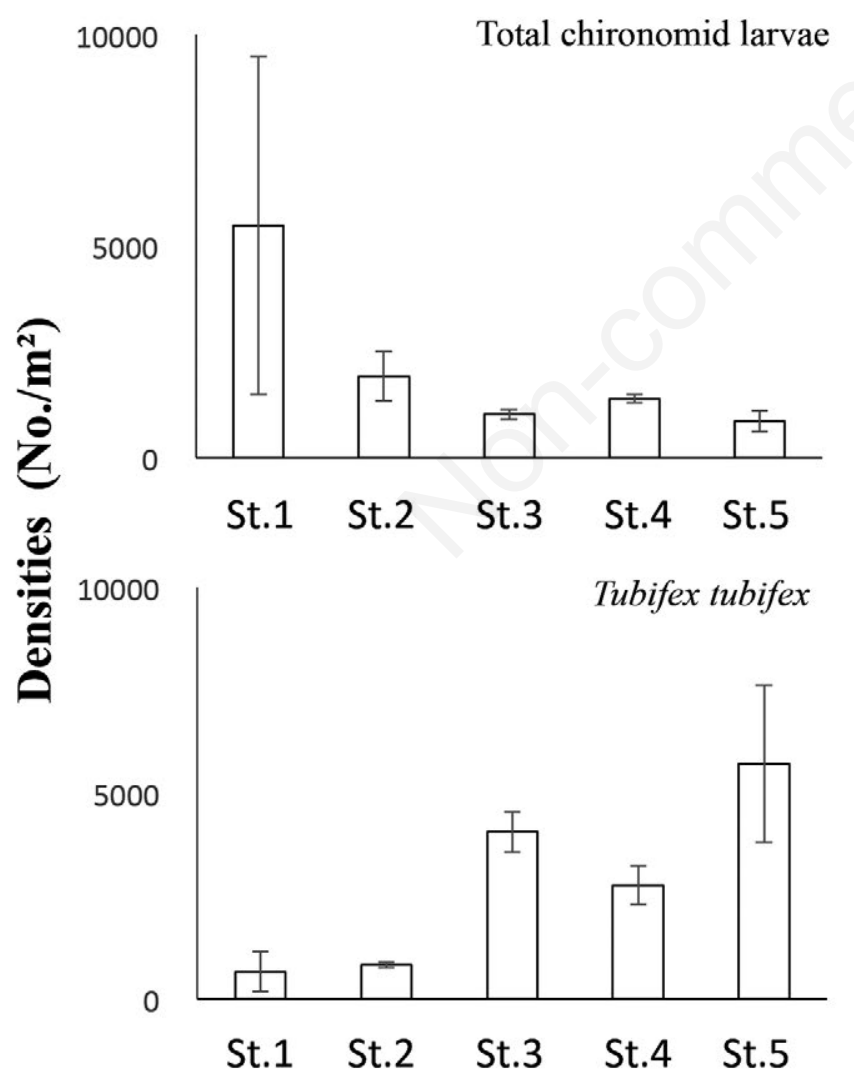

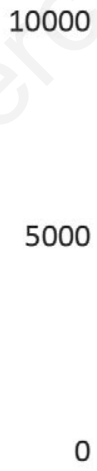

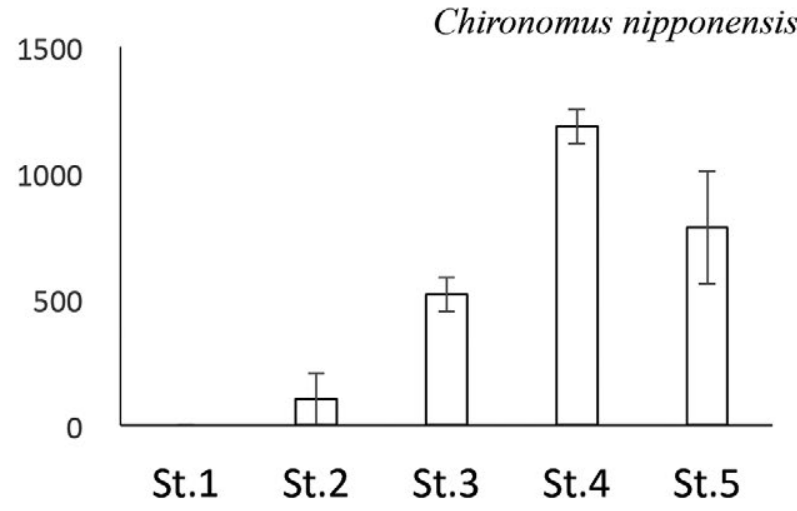

\section{Station}

Fig. 2. Depth distribution of the densities of the main benthos in Lake Nojiri on March 10, 2015. 
tended to increase in deeper regions and has become widely distributed in 2015. Tanytarsus spp. dominated in the chironomid community in the 1930 s, whereas $C$. nipponensis has become dominant in the chironomid community in the last 40 years: density of $C$. nipponensis was $c a$. 14 times higher in 2015 than in 1931 and 4 times higher than in 1973a. We could not compare Miyadi's and Kitagawa's results with ours simply, because the mesh size of the net used is different. But, presumably there were extremely few young age chironomid larvae and immature oligochaetes, i.e., small body size benthos, in March and April (water temperature was $3-5^{\circ} \mathrm{C}$ ). Thus, it would be unlikely that many small size benthos (smaller than $0.5 \mathrm{~mm}$ ) passed through the net at the time of investigation of Miyadi and Kitagawa. Consequently, it seems that there was not any great mistake in a comparison of the densities. Finally, the density of $P$. akamusi, a typical indicator species of hypertrophic or eutrophic lakes (Iwakuma et al., 1988), was low but it was also detected in 2015. Miyadi (1931) and Kitagawa (1973a) also did not describe about this species in other investigation month.

According to Nagano Prefecture (2015), summer stratification occurred in Lake Nojiri from the middle of June to the end of October (TN $0.29 \mathrm{mg} \mathrm{L}^{-1}$, TP $0.005 \mathrm{mg}$ $\mathrm{L}^{-1}$, Transparency $7.5 \mathrm{~m}$ in August 2015). From early
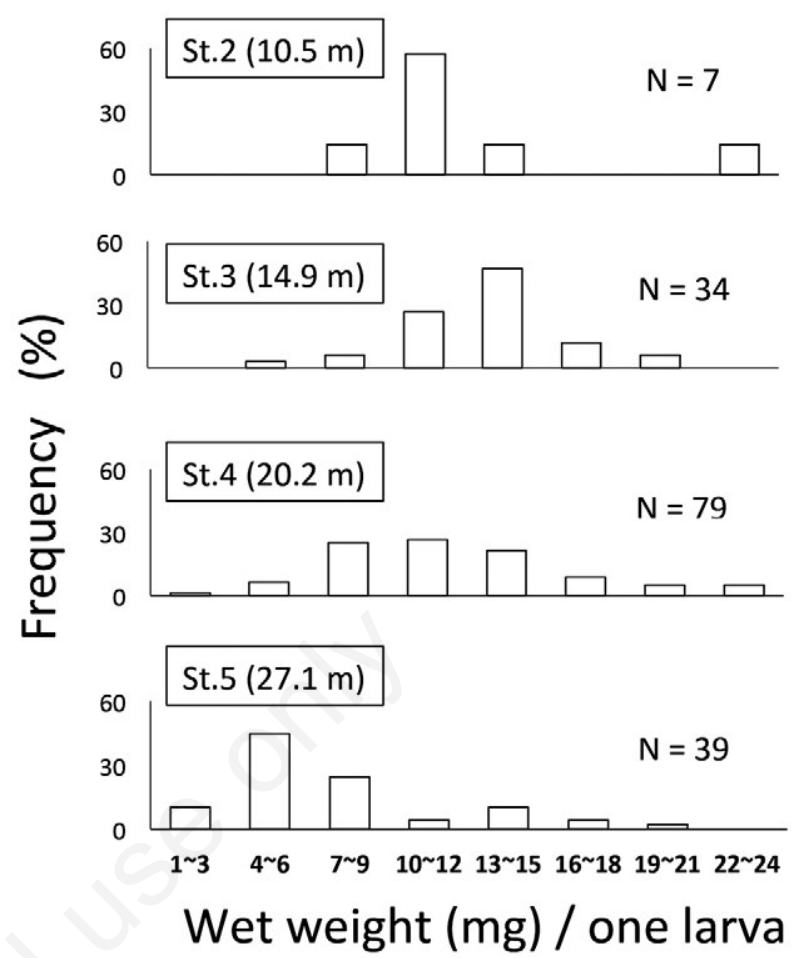

Fig. 3. Percentage frequency of IV-instar larval body wet weight of Chironomus nipponensis Tokunaga at each station in Lake Nojiri on March 10, 2015.

Tab. 2. Changes in densities of chironomid larvae and Tubifex tubifex in Lake Nojiri.

\begin{tabular}{|c|c|c|c|c|c|c|}
\hline & \multicolumn{2}{|c|}{ April, 1928 (Miyadi, 1931) } & \multicolumn{2}{|c|}{ April, 1972 (Kitagawa, 1973a) } & \multicolumn{2}{|c|}{ March, 2015 (Present study) } \\
\hline Sampling sites (No.) & Total 30 & Select $7^{*}$ & Total 12 & Select $8^{*}$ & Total 15 & Select $12^{*}$ \\
\hline Mean depth (m) & $23.6 \pm 12.2$ & $19.0 \pm 7.0$ & $15.3 \pm 6.5$ & $14.8 \pm 5.3$ & $15.8 \pm 7.6$ & $18.2 \pm 6.5$ \\
\hline Chironomidae & $739.0 \pm 895.7$ & $910.2 \pm 1197.4$ & $300.0 \pm 312.0$ & $219.4 \pm 294.0$ & $2128.2 \pm 2330.4$ & $1295.0 \pm 512.2$ \\
\hline Tanypodinae & $85.3 \pm 97.3$ & $68.2 \pm 88.7$ & & $222.0 \pm 171.1$ & $196.1 \pm 168.8$ & \\
\hline Procladius sp. & - & - & $37.5 \pm 91.7$ & $16.9 \pm 33.5$ & - & - \\
\hline \multicolumn{7}{|l|}{ Orthocladiinae } \\
\hline Heterotrissocladius sp. & - & - & - & - & $766.6 \pm 1615.2$ & $136.9 \pm 225.2$ \\
\hline Propsilocerus akamusi & - & - & $3.8 \pm 13.0$ & $5.6 \pm 15.9$ & $11.8 \pm 20.3$ & $14.8 \pm 21.9$ \\
\hline Spamiotoma sp. & - & - & $3.8 \pm 13.0$ & $5.6 \pm 15.9$ & - & - \\
\hline \multicolumn{7}{|l|}{ Chironominae } \\
\hline Chironomus nipponensis & $160.4 \pm 238.9$ & $45.5 \pm 93.9$ & $161.3 \pm 228.2$ & $157.5 \pm 274.3$ & $518.0 \pm 463.1$ & $647.5 \pm 426.1$ \\
\hline Micropsectra sp. & - & - & - & - & $390.7 \pm 557.4$ & $207.2 \pm 274.6$ \\
\hline Stictochironomus multannulatus & - & - & - & - & $79.9 \pm 166.3$ & $44.4 \pm 103.7$ \\
\hline Nilodosis sp. & - & - & - & - & $32.6 \pm 74.0$ & $7.4 \pm 17.3$ \\
\hline Phaenopsectra sp. & - & - & $75.0 \pm 219.1$ & $16.9 \pm 33.5$ & - & - \\
\hline Calopsectra sp. & - & - & $18.8 \pm 35.7$ & $16.9 \pm 33.5$ & - & - \\
\hline Cryptochironomus sp. & $10.6 \pm 57.0$ & $34.1 \pm 102.4$ & - & - & - & - \\
\hline Tanytarsus spp. & $416.4 \pm 831.2$ & $745.2 \pm 1010.5$ & - & - & - & - \\
\hline \multicolumn{7}{|l|}{ Diamesinae } \\
\hline Protanypus sp. & - & - & - & - & $5.9 \pm 22.9$ & - \\
\hline Other chironomid (include pupae) & $66.6 \pm 97.1$ & $17.1 \pm 51.2$ & - & - & $77.0 \pm 127.2$ & $25.9 \pm 51.7$ \\
\hline Unknown chironomid larvae & - & - & - & - & $23.7 \pm 50.0$ & $14.8 \pm 51.3$ \\
\hline Tubifex tubifex & $297.0 \pm 255.6$ & $159.3 \pm 158.7$ & $131.3 \pm 109.3$ & $140.6 \pm 113.9$ & $2809.0 \pm 2138.4$ & $3344.8 \pm 2052.4$ \\
\hline
\end{tabular}


November, dissolved oxygen concentration near the bottom dropped below $1 \mathrm{mg} \mathrm{L}^{-1}$, the lowest oxygen level observed from the 1980s. Tanaka (1992) reported that the anoxic-layer and anaerobic-layer were thickening, especially, in deeper regions. We found a difference in the C. nipponensis body size of the IV-instar larvae collected at different depths, i.e., there are many relatively small ones in deeper Station $5(27.1 \mathrm{~m})$. Rempel and Carter (1987) and Gresens (1997) reported water temperature effects on growth of chironomid larvae. While Jonasson (1965) reported that the growth of Chironomus anthracinus Zetterstedt stopped during the summer stagnation period in the profundal zone where the dissolved oxygen concentration drops below $1 \mathrm{mg} \mathrm{L}^{-1}$. This was due to the decrease and stop of feeding at oxygen concentrations below 2-3 $\mathrm{mg} \mathrm{L}^{-1}$ and $1 \mathrm{mg} \mathrm{L}^{-1}$, respectively. Iwakuma et al. (1993) and Hirabayashi et al. (1996) suggested that $C$. nipponensis might react in the same way under hypoxia/anoxia. According to these findings, low dissolved oxygen concentration combined with low water temperature may have suppressed the growth of $C$. nipponensis during summer-fall. As a result, it seems that the small body size larvae dominated at the deepest station.

Human activity around the lake during 1930s to 2015 was drastically changed in the water condition and biota in this lake, and these large environmental changes may have affected chironomid and T. tubifex density and $C$. nipponensis growth rate especially in the deeper regions with low dissolved oxygen concentrations, low water temperature and high organic matter (ignition loss: $15.0 \%$ in St. 4 and $13.9 \%$ in St. 5) in the sediments. We previously investigated species composition, density, biomass and distribution pattern of benthic fauna in a wide range of mesotrophic/eutrophic lakes: Lake Shoji (shallow eutrophic; Hirabayashi et al., 2012), Lake Kawaguchi (shallow mesotrophic-eutrophic; Hirabayashi et al., 2008), Lake Yamanaka (shallow mesotrophic; Hirabayashi et al., 2004), Lake Kizaki (deep mesotrophiceutrophic; Hirabayashi et al., 1994) and Lake Suwa (shallow hypertrophic; Hirabayashi et al., 2003). In comparison with data of the 1930s (Miyadi, 1931, 1932) and 1970s (Kitagawa, 1973a, 1973b), the present lake bottom environment has greatly changed in these lakes, i.e., an anoxic layer develops during the summer in the deeper regions, as a result of which oligochaetes became dominant taxa, especially $T$. tubifex. In addition, chironomid larvae were not inhabiting the deeper regions and might be restricted to shallower regions. Consequently, we point out a common trend in all the other lakes mentioned above: the densities and biomass of oligochaetes and chironomid larvae have increased in these lakes, especially P. akamusi and T. tubifex. Our study highlighted the same trend in Lake Nojiri.
In our study, biomass of chironomid larvae seemed to be a useful criterion to define the trophic state of Lake Nojiri, according to Yasuno et al. (1983). In Japan, Yasuno et al. (1983) reported that the biomass of chironomid larvae exhibited a positive correlation with Carlson's TSI. Moreover, they proposed an equation of relationship with biomass of chironomid larvae and TSI in Japanese lakes, i.e., $\log \mathrm{Y}=0.04 \mathrm{X}+1.85$, $\mathrm{Y}$ : Biomass of chironomid larvae (wet weight $\mathrm{mg} \mathrm{m}^{-2}$ ), X: Carlson TSI. We estimated Carlson's TSI from chironomid biomass to be 50.8, categorized as a "Mesotrophic-eutrophic lake." Aizaki et al. (1981) and Otsuki et al. (1981) reported the modified Carlson's TSI to be useful as one of the water quality criteria for the trophic state of lakes. In recent years, the densities of $C$. nipponensis and T. tubifex have shown a tendency to increase. T. tubifex was widely distributed especially in deeper regions of Lake Nojiri, indicating that it is in the process of eutrophication. Although classified as mesotrophic in previous studies (Aizaki et al., 1981), our findings suggest that the status of Lake Nojiri should be reclassified.

\section{CONCLUSIONS}

Large environmental changes during the 1930s to 2015 must have affected chironomid and oligochaete densities and growth rate of C. nipponensis, especially in the deeper regions with low dissolved oxygen concentrations, low water temperature and high organic matter in the sediments of Lake Nojiri. This is strong evidence that the eutrophication of this lake is proceeding. Densities, biomass and the distribution pattern of chironomid larvae and oligochaetes seemed to be useful criteria to define the trophic state.

\section{ACKNOWLEDGEMNTS}

The authors thank Mr. Masaaki Takeda for his field work help and two anonymous referees read an earlier version of this paper and made many valuable comments that resulted in its improvement. This study was partly supported by a grant-in-aid for scientific research (No. 24241078) from the Japan Society for the Promotion of Science.

\section{REFERENCES}

Aizaki M, Otsuki A, Fukushima T, Kawai T, Hosomi M, Muraoka K, 1981. Application of modified Carlson's trophic state index to Japanese lakes and its relationships to other parameters related to trophic state. Res. Rep. Nat. Inst. Environ. Stud. 23:13-31.

Andersen T, Cranston PS, Epler J, 2013. The larvae of 
Chironomidae (Diptera) of the Holarctic Region - Keys and diagnoses. Scandinavian Entomology, Lund: 573 pp.

Brinkhurst RO, 1974. The benthos of lakes. McMillan Press, London: $190 \mathrm{pp}$.

Carlson RE, 1977. A trophic state index for lakes. Limnol. Oceanogr. 22:361-369.

Carlson RE, 1980. More complications in the chlorophyllSecchi disk relationship. Limnol. Oceanogr. 25:379-382.

Cranston PS, 1982. A key to the larvae of the British Orthocladiinae (Chironomidae). Freshwater Biological Association Scientific Publicatio: 152 pp.

Gresens SE, 1997. Interactive effects of diet and thermal regime on growth of the midge Pseudochironomus richardsoni Malloch. Freshwater Biol. 38:365-373.

Higuchi S, 2002. How to restore Nitellopsis obtuse in Nojiriko. Bull. Nojiro-ko Museum 10:45-48.

Hirabayashi K, Hayashi H, 1994. Horizontal distribution of benthic macroinvertebrates in Lake Kizaki, Japan. Jap. J. Limnol. 55:105-114.

Hirabayashi K, Hayashi H, 1996. Seasonal variation of Chironomus nipponensis (Diptera) voltinism in the deep mesotrophic Lake Kizaki, Japan. Arch. Hydrobiol. 138: 229-244.

Hirabayashi K, Hanazato T, Nakamoto N, 2003. Population dynamics of Propsilocerus akamusi and Chironomus plumosus (Diptera: Chironomidae) in Lake Suwa in relation to changes in the lake's environment. Hydrobiologia 506509:381-388.

Hirabayashi K, Yoshizawa K, Yoshida N, Kazama F, 2004. Progress of eutrophication and change of chironomid fauna in Lake Yamanakako, Japan. Limnology 5:47-53.

Hirabayashi K, Yoshizawa K, Oga K, Yoshida N, Ariizumi K, Kazama F, 2008. Change of chironomid fauna (Diptera) in eutrophic Lake Kawaguchi, Japan. Bol. Mus. Mun. Funchal, Sup. 13:109-117.

Hirabayashi K, Fu Z, Yoshida N, Yoshizawa K, Kazama F, 2012. A comparison of results from previous and present investigations of benthic macroinvertebrates in the small and shallow Lake Shoji, Fuji Five Lakes, Japan. Fauna Norvegica 31:47-54.

Inoue E, Yamamoto M, Hirabayashi K, 2010. Benthic macroinvertebrates in the Nishina Three Lakes and Lake Nojiri, highland lakes in Japan. Rep. Res. Edu. Ctr. Inlandwat. Environ. 6:95-101.

Iwakuma T, Ueno R, Nohara S, 1993. Distribution and population dynamics of chironomidae (Diptera) in Lake Yunoko, Japan. Jpn. J. Limnol. 54:199-212.

Iwakuma T, Yasuno M, 1981. Chironomid populations in highly eutrophic Lake Kasumigaura. Verh. Internat. Verein. Limnol. 21:664-674.

Iwakuma T, Yasuno M, Sugaya Y, Sasa M. 1988. Three large species of Chironomidae (Diptera) as biological indicators of lake eutrophication, p.101-113. In: M. Yasuno and B.A.Whitton (eds.), Biological monitoring of environmental pollution. Tokai University Press, Tokyo.

Jonasson PM, 1965. Facyors determining population size of Chironomus anthracinus in Lake Esrom. Mitt. Int. Verein. Limnol. 13:139-162.

Kitagawa N, 1973a. [Studies on the bottom fauna of Lakes Kizaki-ko, Aoki-ko, Nakatsuna-ko, Nojiri-ko and Suwako].[Article in Japanese] Jpn. J. Limnol. 34:12-23.

Kitagawa N, 1973b. [ Studies on the bottom fauna of The Fuji Five Lakes and Lake Ashino].[Article in Japanese]. Rikusui Fueiyouka no Kisotekikenkyu 2:32-37.

Kitano S, Higuchi S, Kondo Y, Yamakawa A, Sakai M, Sakai K, Fukase H, 2010. Sunfish invasion inferred from underwater bio-monitoring films during 1996-2008 in Lake Nojiri. Bull. Nagano Environ. Conserv. Res. Inst. 6:51-54.

Lindegaard C, 1995. Classification of water-bodies and pollution, p. 385-404. In: P.D. Armitage, P.S. Cranston and L.C.V. Pinder (eds.), The Chironomidae: Biology and ecology of non-biting midges. Chapman \& Hall, London.

Miyadi D, 1931. Studies on the bottom fauna of Japanese lakes. 1. Lakes of Shinano Province. Jap. J. Zool. 5:201-257.

Miyadi D, 1932. Studies on the bottom fauna of Japanese lakes. 5. Five Lakes at the north foot of Mt. Hudi and Lake Asi. Jap. J. Zool. 4:81-125.

Nagano Prefecture, 2015. The water quality of Lake Nojiri. Nagano Prefecture, Japan.

Otsuki A, Aizaki M, Kawai T, Fukushima T, 1981. Application of Carlson's trophic state index to Japanese lakes. Res. Rep. Nat. Inst. Environ. Stud. 23:3-12.

Rempel RS, Carter JCH, 1987. Temperature influence on adult size, development, and reproductive potential of aquatic diptera. Can. J. Fish. Aquat. Sci. 44:1743-1752.

Sæther OA, 1979. Chironomid communities as water quality indicator. Holarct. Ecol. 2:65-74.

Tanaka A, 1916. [Study of Lake Nojiri].[Book in Japanese]. Shinano-kyoikukai Kamiminochi -bukai, Kokin-shyoin, Tokyo.

Tanaka M, 1992. [The lakes in Japan].[Book in Japanese]. Nagoya University Press, Nagoya.

Wiederholm T, 1983. Chironomidae of the Holarctic region. Keys and Diagnoses. Part 1. Larvae. Ent. Scand. Suppl. 19:1-482.

Yamagishi H, Fukuhara H, 1972. Vertical migration of Spaniotoma akamusi larvae (Diptera: Chironomidae) through the bottom deposits of Lake Suwa. Jap. J. Ecol. 22:226-227.

Yasuno M, Iwakuma T, Sugaya Y, Sasa M, 1983. Zoobenthos of Japanese lakes of different trophic status, with special reference to Chironomidae. Res. Rep. Special Res. Proj. Environ. Sci. B182-R12-17:21-48. 